Article

\title{
Antioxidant Peptides from Goat Milk Fermented by Lactobacillus casei L61: Preparation, Optimization, and Stability Evaluation in Simulated Gastrointestinal Fluid
}

\author{
Guowei Shu ${ }^{1, *(\mathbb{D})}$, Xiaoyu Shi ${ }^{1}$, Li Chen ${ }^{2, *(\mathbb{D})}$, Jianbo Kou ${ }^{1}$, Jiangpeng Meng ${ }^{3}$ and He Chen ${ }^{1}$ \\ 1 School of Food and Biological Engineering, Shaanxi University of Science and Technology, \\ Xi'an 710021, China; shixiaoyu419@163.com (X.S.); lcshgw@gmail.com (J.K.); chenhe419@gmail.com (H.C.) \\ 2 College of Food Engineering and Nutritional Science, Shaanxi Normal University, Xi'an 710119, China \\ 3 Department of Research and Development, Xi'an Baiyue Gaot Milk Corp., Ltd., Xi'an 710089, China; \\ byjpmeng@gmail.com \\ * Correspondence: shuguowei@gmail.com (G.S.); chenlisp@snnu.edu.cn (L.C.); Tel.: +86-029-8616-8589 (G.S.); \\ Tel./Fax: +86-029-8531-0517 (L.C.)
}

Received: 10 May 2018; Accepted: 18 June 2018; Published: 20 June 2018

\begin{abstract}
Antioxidant peptides are currently the focus of many studies, since they eliminate free radicals in the human body without harmful effects. In the present study, Lactobacillus casei L61 was used as a starter culture to ferment goat milk because of its high capacity to produce antioxidant peptides. An optimal nutrients formula (casein, casein peptone, glucose, soybean peptone, inulin, calcium lactate, and cysteine) was investigated by Plackett-Burman (P-B) and Box-Behnken (B-B) designs for response surface methodology (RSM). Antioxidant peptides were successively isolated and purified from the fermented goat milk. Furthermore, the stability of the antioxidant peptides was evaluated in a simulated gastrointestinal tract at $37^{\circ} \mathrm{C}$. The results showed that calcium lactate, glucose, and casein peptone significantly affected the antioxidant activity of goat milk. The optimal additive amounts were $0.99 \%(w / v)$ calcium lactate, $0.21 \%(w / v)$ glucose, and $0.29 \%$ $(w / v)$ casein peptone. The hydroxyl free radical scavenging rate increased significantly $(p<0.001)$ from $56.50 \pm 0.57 \%$ to $88.01 \pm 0.69 \%$; the 1,1-diphenyl-2-picrylhydrazyl (DPPH) radical scavenging rate increased up to $63.48 \pm 1.22 \%$ under the optimal conditions $(n=3)$. Our research provides a fitted mathematical model for antioxidant peptides production. Besides, these antioxidant peptides had great stability during simulated gastrointestinal digestion.
\end{abstract}

Keywords: goat milk; antioxidant peptides; Lactobacillus casei L61; response surface methodology; simulated gastrointestinal digestion; scavenging rate of hydroxyl radical; DPPH

\section{Introduction}

Free radicals are generated inevitably as by-products during aerobic metabolism, generally as reactive oxidant species (ROS) [1]. The most common ROS in vivo are superoxide, hydroxyl radical, peroxyl radical, nitric oxide, and peroxynitrite [2]. As a result of the oxidation of excessive free radicals, a series of free-radical chain reactions are triggered, causing oxidative damage to proteins, enzymes, lipids, and nucleic acids in the body [3]. This will have a harmful impact on organs and tissues [4], promoting heart disease, diabetes, cancer, and cataracts.

At present, antioxidants are effective compounds for scavenging free radicals and have been widely used in many fields. Studies have shown that supplements which are rich in antioxidant activity can reduce oxidative damage in the human body [5]. However, artificial antioxidants, such as 
butylated hydroxyanisole (BHA), butylated hydroxytoluene (BHT) and t-butylhydroquinone (TBHQ) probably have potential health hazards to the human body [6]. Because of their strong antioxidant activity and high safety, natural antioxidants have gradually attracted considerable attention.

As facultative anaerobic microorganisms, lactic acid bacteria (LAB) were generally investigated for their response to oxidative stresses, the ability to remove radicals, and the production of antioxidant enzymes in cells grown anaerobically [7]. Besides, various bioactive peptides have been isolated from protein hydrolysates fermented by LAB, which were proved to be functional in health promotion. The production of peptides by a hydrolytic reaction is the most promising technique, since peptides have substantially higher antioxidant activity than intact proteins [8]. Goat milk is rich in various protein activities, with an unparalleled advantage. The proteins, fats, minerals, vitamins, and other nutrients of goat milk provide many benefits compared to other types of milk [9-11]. Moreover, goat milk overall protein particles are smaller, and its fat is composed of short-chain fatty acids. It is closer to human breast milk than other milk types, and has even a higher level of immunoglobulin than breast milk [12]. So far, 28 small peptides with antioxidant activity have been identified from goat cheese by Sommerer et al. [13]. A research by Li et al. [14] described the preparation, purification, and identification of antioxidant peptides from goat milk casein. Five novel oligopeptides were identified. Two milk protein-derived peptides with sequences of VKEAMAPK and HIQKEDVPSER have been identified from cheddar cheese fermented by Lactobacillus casei ssp. casei 300 [15].

In our previous work, L. casei L61 was selected as the starter of antioxidant peptides among four probiotic Lactobacillus strains. The factors (casein, casein peptone, glucose, soybean peptone, inulin, calcium lactate, and cysteine) affecting the antioxidant activity of L. casei L61 in fermented goat milk were investigated by single factor experiments (data unpublished). In this study, we screen and optimize a nutrients formula for goat milk fermentation, aiming to promote antioxidant peptides production by Plackett-Burman (P-B) and Box-Behnken (B-B) design for response surface methodology (RSM). Subsequently, the antioxidant peptides are isolated and purified from goat milk fermented by L. casei L61 and exposed to simulated gastrointestinal fluid during different times for stability evaluation.

\section{Materials and Methods}

\subsection{Strain}

L. casei L61 was provided by the college of Food and Biological Engineering, Shaanxi University of Science \& Technology ( $\mathrm{Xi}^{\prime}$ an, China). The starter cultures were stored at $-20^{\circ} \mathrm{C}$ in freeze-dried powder by using skim goat milk as a cryoprotective agent. L. casei L61 was activated successively three times in rehydrated Man Rogosa Sharpe broth (MRS, Hopebio, Qingdao, China) with a 5\% inoculum at $37^{\circ} \mathrm{C}$ for $24 \mathrm{~h}$ prior to use as starter culture to ferment goat milk.

\subsection{Preparation of Fermented Goat Milk and Whey Fractions}

A starter culture containing L. casei L61 was inoculated into $100 \mathrm{~mL} 12.5 \%(w / v)$ of reconstituted goat milk pasteurized at $90{ }^{\circ} \mathrm{C}$ for 15 min with a $5 \%$ inoculum and fermented at $41{ }^{\circ} \mathrm{C}$ for $16 \mathrm{~h}$. Fermented goat milk was adjusted to $\mathrm{pH} 3.4-3.6$ and centrifuged at $5000 \times \mathrm{g}$ for $15 \mathrm{~min}$ at $4{ }^{\circ} \mathrm{C}$ to obtain a supernatant. The supernatant was collected, adjusted to $\mathrm{pH} 8.3$, and centrifuged at $5000 \times g$ for $15 \mathrm{~min}$ at $4{ }^{\circ} \mathrm{C}$ to obtain the corresponding whey fraction, which was used for the determination of the antioxidant activity.

\subsection{Determination of Hydroxyl Free Radical Scavenging Rate}

The hydroxyl free radical scavenging rate was measured according to the method of Kong et al. [16] with modifications. A sample solution of $0.5 \mathrm{~mL}$ was pipetted into a test tube, and $1 \mathrm{~mL}$ ferrous chloride solution $(0.25 \mathrm{mmol} / \mathrm{L})$ and ferrozine solution $(0.5 \mathrm{mmol} / \mathrm{L})$ was added. The sample was placed for $10 \mathrm{~min}$ at room temperature after mixing it thoroughly. Distilled water was used as a control. The absorbance at $562 \mathrm{~nm}$ 
was measured in triplicate using a UV-vis spectrophotometer (Shanghai Spectrum Instruments Co., Ltd., Shanghai, China). The value of the hydroxyl free radical scavenging rate was calculated as follows:

$$
\text { hydroxyl free radical scavenging rate }=\left(\mathrm{A}_{2}-\mathrm{A}_{1}\right) / \mathrm{A}_{2} \times 100 \%
$$

where $A_{1}$ is the absorbance of the experiment group, and $A_{2}$ is the absorbance of the control group.

\subsection{Determination of 1,1-diphenyl-2-picrylhydrazyl (DPPH) Radical Scavenging Rate}

The measurement of the DPPH radical scavenging rate was based on the method of Kazuko et al. [17] with modifications. The mixture of $2 \mathrm{~mL}$ of DPPH radical solution ( $0.1 \mathrm{mM}$, USA Sigma, St. Louis, MO, USA) and $2 \mathrm{~mL}$ of samples was selected as the experiment group. The mixture of $2 \mathrm{~mL}$ of DPPH radical solution and $2 \mathrm{~mL}$ of $95 \%$ ethanol was used as the blank group. Also, $2 \mathrm{~mL}$ of $95 \%$ ethanol and $2 \mathrm{~mL}$ of samples were mixed as the control group. Every mixture was kept at $25^{\circ} \mathrm{C}$ for $30 \mathrm{~min}$ after mixing. Finally, the absorbance of the mixture was measured by a UV-vis spectrophotometer at $517 \mathrm{~nm}$; all the tests were carried out in triplicate. The scavenging rate was calculated as follow:

$$
\mathrm{DPPH} \text { radical scavenging rate }=[1-(\mathrm{Ai}-\mathrm{Aj}) / \mathrm{Ao}] \times 100 \%
$$

where $\mathrm{Ai}$ is the absorbance of the experiment group, $\mathrm{Aj}$ is the absorbance of the control group, and Ao is the absorbance of the blank group.

\subsection{P-B Experimental Design}

Many nutrients can be used as a carbon source, a nitrogen source, inorganic salts, and prebiotics to promote the growth of L. casei. Therefore, several nutrients, namely, casein, casein peptone, glucose, soybean peptone, inulin, calcium lactate, and cysteine were selected to conduct the P-B-designed experiment. The experiment of $\mathrm{P}-\mathrm{B}$ design contained seven factors and three error terms, spanning 12 runs at two levels (a higher level coded as +1 , a lower level coded as -1 ) to determine significant factors for the antioxidant activity of goat milk fermented by L. casei L61. The factors and coded levels of the P-B design are shown in Table 1.

Table 1. Factors and coded levels of the Plackett-Burman (P-B) design for peptide productionpromoting nutrients.

\begin{tabular}{ccccccccc}
\hline Factors & $\mathbf{X 1}$ & $\mathbf{X 5}$ & $\mathbf{X 6}$ & $\mathbf{X 7}$ & $\mathbf{X 8}$ & $\mathbf{X 9}$ & X10 \\
\hline \multirow{2}{*}{ Variables } & Casein & Casein Peptone & Glucose & Soybean Peptone & Inulin & Calcium Lactate & Cysteine \\
\cline { 2 - 8 } & $\mathbf{( \% )}$ & $\mathbf{( \% )}$ & $\mathbf{( \% )}$ & $\mathbf{( \% )}$ & $\mathbf{( \% )}$ & $\mathbf{( \% )}$ & $\mathbf{( \% )}$ \\
\hline 1 & 0.25 & 0.875 & 0.75 & 0.625 & 0.5 & 0.625 & 1.25 \\
-1 & 0.2 & 0.7 & 0.6 & 0.5 & 0.4 & 0.5 & 1 \\
\hline
\end{tabular}

X1, X5, X6, X7, X8, X9, X10 represent casein, casein peptone, glucose, soybean peptone, inulin, calcium lactate, and cysteine, respectively, while $\mathrm{X} 2, \mathrm{X} 3$, and $\mathrm{X} 4$ are three error terms.

\subsection{Steepest Ascent Experiment}

The steepest ascent experiment contained three significant factors, i.e., calcium lactate, glucose, and casein peptone at different levels and was performed to determine the central points of the RSM for goat milk fermented by L. casei L61. The antioxidant activity of each group of fermented goat milk was measured in triplicate.

\subsection{B-B Design of RSM}

RSM was employed for further optimization studies by determining the maximum response value and evaluating the main effects, interaction effects, and quadratic effects. A three-variable and three-level RSM was used according to the previous study (Table 2). 
Table 2. Factors level-coding table of the Box-Behnken (B-B) design for peptide productionpromoting nutrients.

\begin{tabular}{cccc}
\hline Factors & $\begin{array}{c}\text { A: Calcium Lactate } \\
\mathbf{( \% )}\end{array}$ & $\begin{array}{c}\text { B: Glucose } \\
\mathbf{( \% )}\end{array}$ & $\begin{array}{c}\text { C: Casein Peptone } \\
\mathbf{( \% )}\end{array}$ \\
\hline-1 & 0.9 & 0.1 & 0.2 \\
0 & 1.0 & 0.2 & 0.3 \\
1 & 1.1 & 0.3 & 0.4 \\
\hline
\end{tabular}

\subsection{Isolation and Purification of Antioxidant Peptides}

Fermented goat milk samples with optimal additive amounts of calcium lactate, glucose, and casein peptone were collected and treated to obtain the whey fractions. The supernatants obtained were filtered by ultrafiltration with a cut-off of $3000 \mathrm{Da}$ to isolate the antioxidant peptides. Sephadex G-25 and G-15 were employed to separate and purify the filtrated liquid, using gel filtration chromatography (GFC). The component with the highest activity was collected, freeze-dried, and used to determine the resistance to simulated gastrointestinal fluid.

\subsection{Resistance to Simulated Gastric and Intestinal Fluids}

Simulated gastrointestinal digestion was conducted according to the method of Cruzhuerta et al. [18] with modifications. An amount of $6 \mathrm{mg}$ of the separated components was added to $20 \mathrm{~mL}$ of simulated gastric fluid (1 g pepsin was dissolved in $100 \mathrm{~mL}$ of deionized water, and $1.64 \mathrm{~mL}$ of $0.1 \mathrm{~mol} / \mathrm{L} \mathrm{HCl}$ was added). The samples were incubated for $0 \mathrm{~min}, 40 \mathrm{~min}, 80 \mathrm{~min}, 120 \mathrm{~min}, 160 \mathrm{~min}$, and $200 \mathrm{~min}$ at $37^{\circ} \mathrm{C}$. The reactions were stopped by heating at $80^{\circ} \mathrm{C}$ for $5 \mathrm{~min}$. The hydroxyl free radical and DPPH scavenging rates were measured. An amount of $20 \mathrm{~mL}$ of simulated intestinal fluid $\left(0.68 \mathrm{~g} \mathrm{~K}_{2} \mathrm{HPO}_{4}\right.$ and $1 \mathrm{~g}$ trypsin were dissolved in $100 \mathrm{~mL}$ of deionized water, and the $\mathrm{pH}$ was adjusted to 6.8 using a diluted $\mathrm{NaOH}$ solution) was added to the samples after incubation in the simulated gastric fluid for $40 \mathrm{~min}$. The samples were incubated for $40 \mathrm{~min}, 80 \mathrm{~min}, 120 \mathrm{~min}, 160 \mathrm{~min}$, and $200 \mathrm{~min}$ at $37^{\circ} \mathrm{C}$. The hydroxyl free radical and DPPH scavenging rates were measured after stopping the reactions by heating. All the scavenging rates were measured in triplicate.

\subsection{Statistical Analysis of the Data}

SAS (Version 12.0, SAS Institute Inc., Cary, NC, USA) was used for statistical analysis of the P-B-designed experimental data to identify the significant variables and corresponding coefficients. The coefficient, sum of squares (SS \%), and confidence intervals (CI) were evaluated to analyze the antioxidant activity in each trial.

Design Expert software (Version 8.0.5, Stat-Ease. Inc, Minneapolis, MN, USA) was employed for the analysis of the B-B designed experimental data obtained, and a quadratic regression equation was established to analyze the response surface contour and surface plots.

\section{Results}

\subsection{P-B Experimental Design and Results}

The result of the P-B design are shown in Table 3; $\mathrm{Y}_{1}(\%)$ and $\mathrm{Y}_{2}(\%)$ are the hydroxyl free radical scavenging rate and $\mathrm{DPPH}$ radical scavenging rate, respectively.

$\mathrm{X} 1, \mathrm{X} 5, \mathrm{X6}, \mathrm{X7}, \mathrm{X8}, \mathrm{X} 9, \mathrm{X} 10$ represent casein, casein peptone, glucose, soybean peptone, inulin, calcium lactate, and cysteine, respectively, while $\mathrm{X} 2, \mathrm{X} 3$, and $\mathrm{X} 4$ are three error terms. 
Table 3. P-B design and results for peptide production-promoting nutrients.

\begin{tabular}{ccccccccccccc}
\hline Factors & $\mathbf{X 1}$ & $\mathbf{X 2}$ & $\mathbf{X 3}$ & $\mathbf{X} \mathbf{4}$ & $\mathbf{X 5}$ & $\mathbf{X 6}$ & $\mathbf{X 7}$ & $\mathbf{X 8}$ & $\mathbf{X 9}$ & $\mathbf{X 1 0}$ & $\mathbf{Y}_{\mathbf{1}}$ & $\mathbf{Y}_{\mathbf{2}}$ \\
\hline 1 & 1 & -1 & 1 & -1 & -1 & -1 & 1 & 1 & 1 & -1 & 77.66 & 55.82 \\
2 & 1 & 1 & -1 & 1 & -1 & -1 & -1 & 1 & 1 & 1 & 83.34 & 62.79 \\
3 & -1 & 1 & 1 & -1 & 1 & -1 & -1 & -1 & 1 & 1 & 76.26 & 50.63 \\
4 & 1 & -1 & 1 & -1 & -1 & 1 & -1 & -1 & -1 & 1 & 71.91 & 50.02 \\
5 & 1 & 1 & -1 & 1 & 1 & -1 & 1 & -1 & -1 & -1 & 71.91 & 50.02 \\
6 & 1 & 1 & 1 & 1 & 1 & 1 & -1 & 1 & -1 & -1 & 76.36 & 50.82 \\
7 & -1 & 1 & 1 & -1 & -1 & 1 & 1 & -1 & 1 & -1 & 76.66 & 55.12 \\
8 & -1 & -1 & 1 & 1 & 1 & -1 & 1 & 1 & -1 & 1 & 75.61 & 48.96 \\
9 & -1 & -1 & -1 & 1 & 1 & 1 & -1 & 1 & 1 & -1 & 76.11 & 50.17 \\
10 & 1 & -1 & -1 & -1 & 1 & 1 & 1 & -1 & 1 & 1 & 75.86 & 49.37 \\
11 & -1 & 1 & -1 & -1 & -1 & 1 & 1 & 1 & -1 & 1 & 75.02 & 48.29 \\
12 & -1 & -1 & -1 & -1 & -1 & -1 & -1 & -1 & -1 & -1 & 76.51 & 51.77 \\
\hline
\end{tabular}

The effects of nutrients were different during fermentation, therefore the antioxidant activity changed under different conditions. As shown in Figure 1, three variables, i.e., casein peptone (X5), glucose (X6), and calcium lactate (X9), accounted for a large proportion of the percent sum of squares on the Pareto chart for both hydroxyl free radical scavenging rate and DPPH radical scavenging rate. This indicated that the three variables had significant positive effects on the antioxidant activity (Figure 2). According to the results of the P-B design and principal factor analysis, casein peptone, glucose, and calcium lactate were selected as the main factors for further analysis by the steepest ascent experiment; Y1 (\%) and Y2 (\%) are the hydroxyl free radical scavenging rate and DPPH radical scavenging rate, respectively.

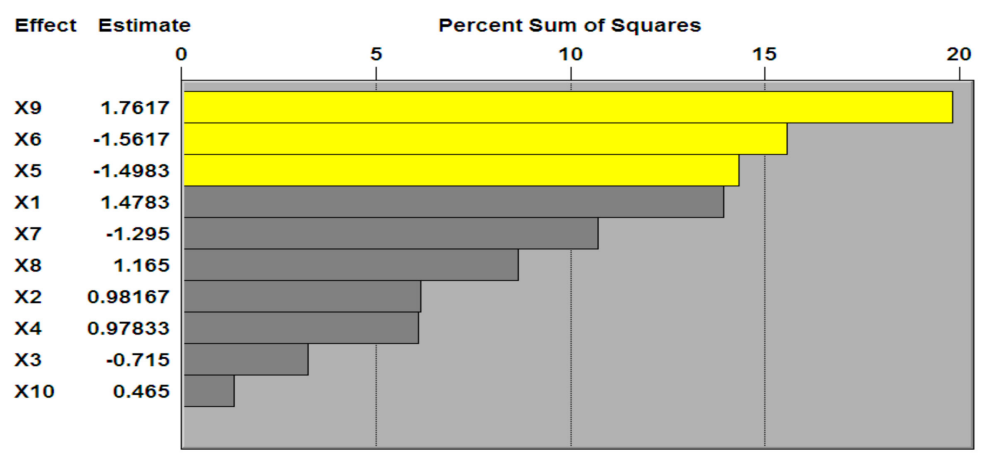

(a)

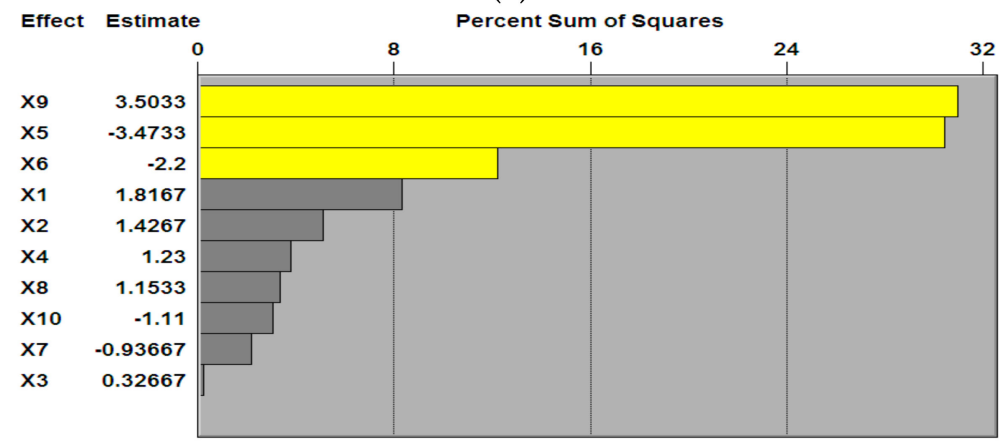

(b)

Figure 1. The effect of variable factors on the hydroxyl free radical scavenging rate (a) and DPPH radical scavenging rate $(\mathbf{b})$. 


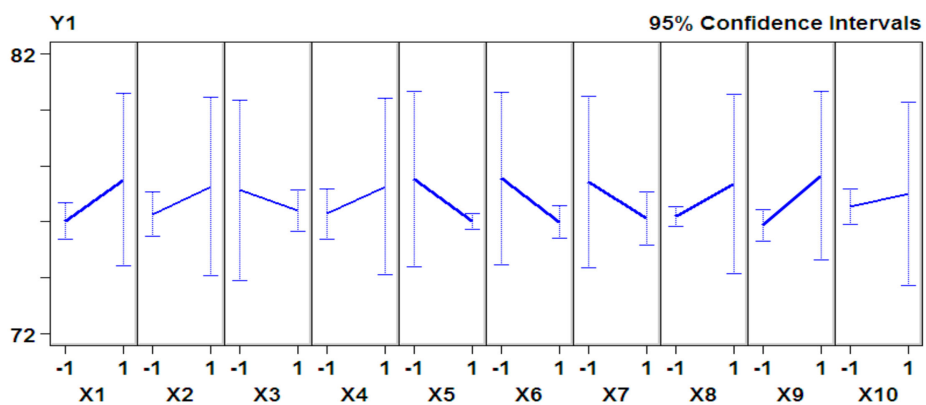

(a)

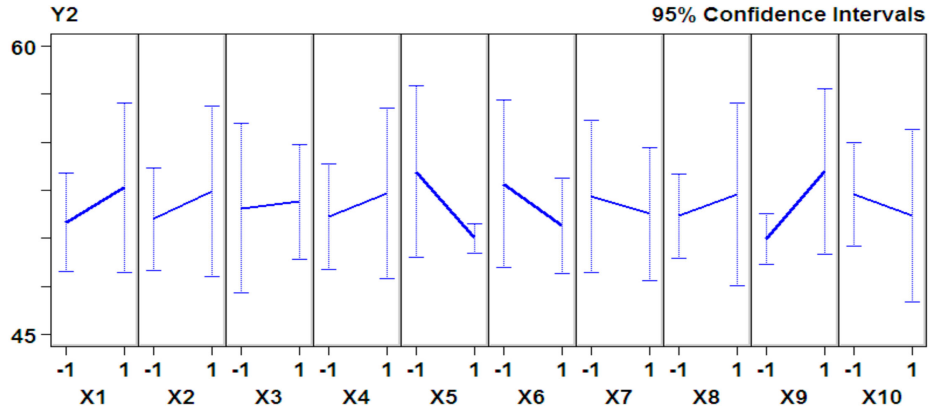

(b)

Figure 2. The confidence interval of variable factors for the hydroxyl free radical scavenging rate (a) and DPPH radical scavenging rate $(\mathbf{b})$.

\subsection{The Experimental Design and Results of the Steepest Ascent Experiment}

The steepest ascent experiment was preformed to determine the central points of the RSM. Table 4 lists the design and results of the steepest ascent experiment for nutrients promoting peptide production. $\mathrm{Y}_{1}(\%)$ and $\mathrm{Y}_{2}(\%)$ represent the hydroxyl free radical scavenging rate and DPPH radical scavenging rate, respectively.

Table 4. Design and results of the steepest ascent experiment for nutrients promoting peptide production.

\begin{tabular}{cccccc}
\hline Step & $\begin{array}{c}\text { Calcium Lactate } \\
\mathbf{( \% )}\end{array}$ & $\begin{array}{c}\text { Glucose } \\
\mathbf{( \% )}\end{array}$ & $\begin{array}{c}\text { Casein Peptone } \\
\mathbf{( \% )}\end{array}$ & $\begin{array}{c}\mathbf{Y}_{\mathbf{1}} \\
\mathbf{( \% )}\end{array}$ & $\begin{array}{c}\mathbf{Y}_{\mathbf{2}} \\
\mathbf{( \% )}\end{array}$ \\
\hline 1 & 0.6 & 0.6 & 0.7 & $79.65 \pm 0.57 \%$ & $47.43 \pm 0.39 \%$ \\
2 & 0.7 & 0.5 & 0.6 & $80.55 \pm 0.61 \%$ & $49.72 \pm 0.48 \%$ \\
3 & 0.8 & 0.4 & 0.5 & $79.69 \pm 0.51 \%$ & $50.14 \pm 0.36 \%$ \\
4 & 0.9 & 0.3 & 0.4 & $80.78 \pm 0.44 \%$ & $61.24 \pm 0.35 \%$ \\
5 & 1.0 & 0.2 & 0.3 & $85.43 \pm 0.32 \%$ & $64.56 \pm 0.62 \%$ \\
6 & 1.1 & 0.1 & 0.2 & $81.48 \pm 0.49 \%$ & $60.31 \pm 0.37 \%$ \\
\hline
\end{tabular}

Mean values $(n=3) \pm$ standard error are shown.

As can be seen from Table 4, both hydroxyl radical scavenging rate and DPPH radical scavenging rate reached the maximum in the fifth step during the steepest ascent experiments. Therefore, the levels of each factor in step five, which were $1.0 \%(w / v)$ for calcium lactate, $0.2 \%(w / v)$ for glucose, and $0.3 \%$ $(w / v)$ for casein peptone, were used as the center points of the subsequent RSM.

\subsection{B-B Experimental Design and Results}

B-B experimental design and results are shown in Table 5. The hydroxyl free radical scavenging rate is represented by $\mathrm{Y}_{1}(\%)$, and the DPPH radical scavenging rate is represented by $\mathrm{Y}_{2}(\%)$. 
Table 5. B-B experimental design and results for nutrients promoting peptide production. A, calcium lactate; $\mathrm{B}$, glucose; $\mathrm{C}$, casein peptone.

\begin{tabular}{|c|c|c|c|c|c|c|c|c|c|}
\hline \multirow[b]{2}{*}{ Runs } & \multirow[b]{2}{*}{ A } & \multirow[b]{2}{*}{ B } & \multirow[b]{2}{*}{$\mathrm{C}$} & \multicolumn{3}{|c|}{$\mathrm{Y}_{1}(\%)$} & \multicolumn{3}{|c|}{$\mathrm{Y}_{2}(\%)$} \\
\hline & & & & $\begin{array}{l}\text { Actual } \\
\text { Value }\end{array}$ & $\begin{array}{l}\text { Predicted } \\
\text { Value }\end{array}$ & Residual & $\begin{array}{l}\text { Actual } \\
\text { Value }\end{array}$ & $\begin{array}{l}\text { Predicted } \\
\text { Value }\end{array}$ & Residual \\
\hline 1 & 0 & 1 & -1 & 86.84 & 86.67 & 0.07 & 52.92 & 51.68 & 1.24 \\
\hline 2 & 1 & 0 & -1 & 85.42 & 85.00 & -0.42 & 59.59 & 59.74 & -0.15 \\
\hline 3 & 0 & 0 & 0 & 87.86 & 88.14 & -0.28 & 64.51 & 63.89 & -0.62 \\
\hline 4 & 1 & 1 & 0 & 83.56 & 84.15 & -0.59 & 51.9 & 52.99 & -1.09 \\
\hline 5 & 1 & 0 & 1 & 78.23 & 78.52 & -0.29 & 50.08 & 49.91 & 0.17 \\
\hline 6 & -1 & -1 & 0 & 85.72 & 85.14 & 0.58 & 55.72 & 54.63 & 1.09 \\
\hline 7 & -1 & 1 & 0 & 85.38 & 85.83 & -0.45 & 58.3 & 59.37 & -1.07 \\
\hline 8 & 1 & -1 & 0 & 82.12 & 81.67 & 0.45 & 64.92 & 63.86 & 1.06 \\
\hline 9 & 0 & 0 & 0 & 87.86 & 88.14 & 0.66 & 63.67 & 63.89 & -0.22 \\
\hline 10 & 0 & 0 & 0 & 88.69 & 88.14 & 0.55 & 63.5 & 63.89 & -0.39 \\
\hline 11 & -1 & 0 & 1 & 84.92 & 85.34 & -0.42 & 54.71 & 54.57 & 0.14 \\
\hline 12 & 0 & 1 & 1 & 85.73 & 84.86 & 0.87 & 47.12 & 46.20 & 0.95 \\
\hline 13 & 0 & -1 & -1 & 84.64 & 85.51 & -0.87 & 52.08 & 53.00 & -0.92 \\
\hline 14 & 0 & -1 & 1 & 82.69 & 82.86 & -0.17 & 49.76 & 51.00 & -1.24 \\
\hline 15 & -1 & 0 & -1 & 83.61 & 83.33 & 0.28 & 52.04 & 52.22 & -0.18 \\
\hline
\end{tabular}

A, B, and C represent calcium lactate, glucose, and casein peptone.

The data were analyzed to get a quadratic regression model by using Design Export based on the data from the B-B experiment. A multiple regression equation correlating the response function with the independent variables could be obtained as:

$$
\begin{aligned}
& Y_{1}=88.14-1.29 A+0.79 B-1.12 C+0.45 A B-2.13 A C+0.21 B C-2.94 A^{2}-1.01 B^{2}-2.16 C^{2} \\
& Y_{2}=63.89+0.71 A-1.53 B-1.87 C-3.90 A B-3.05 A C-0.87 B C-1.27 A^{2}-4.91 B^{2}-8.51 C^{2}
\end{aligned}
$$

where $Y_{1}$ and $Y_{2}$ are the corresponding expected values of the hydroxyl free radical scavenging rate and the DPPH radical scavenging rate, and $\mathrm{A}, \mathrm{B}$, and $\mathrm{C}$ are the coded values of the independent variables calcium lactate, glucose, and casein peptone, respectively.

Analysis of variance (ANOVA) was used to verify the validity of the model and its parameters according to the significance, as shown in Table $6 . Y_{1}(\%)$ and $Y_{2}(\%)$ represent the hydroxyl free radical scavenging rate and DPPH radical scavenging rate, respectively.

Table 6. ANOVA of the response variables for the hydroxyl free radical scavenging rate $\left(\mathrm{Y}_{1}\right)$ and the

\begin{tabular}{|c|c|c|c|c|c|c|c|}
\hline \multirow{2}{*}{ Source } & \multicolumn{4}{|c|}{$Y_{1}$} & \multicolumn{3}{|c|}{$\mathrm{Y}_{2}$} \\
\hline & DF & MS & $\mathbf{F}$ & $\operatorname{Pr}>F$ & MS & F & $\operatorname{Pr}>F$ \\
\hline Model & 9 & 10.50 & 14.45 & $0.0045^{* *}$ & 54.11 & 26.73 & 0.0010 ** \\
\hline $\mathrm{A}$ & 1 & 13.26 & 18.26 & $0.0079^{* *}$ & 4.09 & 2.02 & 0.2145 \\
\hline B & 1 & 5.02 & 6.92 & $0.0465 *$ & 18.73 & 9.25 & 0.0287 * \\
\hline $\mathrm{C}$ & 1 & 9.99 & 13.75 & $0.0139 *$ & 27.98 & 13.82 & $0.0138^{*}$ \\
\hline $\mathrm{AB}$ & 1 & 0.79 & 1.09 & 0.3442 & 60.84 & 30.05 & $0.0028^{* *}$ \\
\hline $\mathrm{AC}$ & 1 & 18.06 & 24.86 & $0.0042^{* *}$ & 37.09 & 18.32 & $0.0079 * *$ \\
\hline $\mathrm{BC}$ & 1 & 0.18 & 0.24 & 0.6430 & 3.03 & 1.50 & 0.2759 \\
\hline$A^{2}$ & 1 & 31.82 & 43.81 & $0.0012 * *$ & 5.99 & 2.96 & 0.1459 \\
\hline $\mathrm{B}^{2}$ & 1 & 3.74 & 5.14 & 0.0727 & 88.98 & 43.95 & $0.0012^{* *}$ \\
\hline$C^{2}$ & 1 & 17.16 & 23.62 & $0.0046^{* *}$ & 267.66 & 132.21 & $<0.0001^{* * *}$ \\
\hline Residual & 5 & 0.73 & & & 2.02 & & \\
\hline Lack of fit & 3 & 1.06 & 4.61 & 0.1835 & 3.18 & 10.87 & 0.0854 \\
\hline Pure error & 2 & 0.23 & & & 0.29 & & \\
\hline Cor Total & 14 & & & & & & \\
\hline
\end{tabular}
DPPH radical scavenging rate $\left(\mathrm{Y}_{2}\right)$.

*** $p<0.001$, extremely significant; ${ }^{* *} p<0.01$, very significant; ${ }^{*} p<0.05$, significant. DF refers to degrees of freedom, $\mathrm{MS}$ refers to mean square, $\mathrm{F}$ and $\mathrm{Pr}>\mathrm{F}$ refer to $\mathrm{F}$ and $p$-values, respectively. 
As shown in Table 6, a significant value for the hydroxyl free radical scavenging rate $(p=0.0045<0.01)$ and an insignificant value of the lack of fit $(p=0.1835>0.05)$ revealed the effectiveness of the regression analysis, which suggested that the regression model could be used to fit the effect of the three factors on hydroxyl free radical scavenging rate. As the ratio of the explained variation to the total variation, the coefficient of determination $\left(\mathrm{R}^{2}\right)$ can be used to measure the degree of fit. The value of $\mathrm{R}^{2}$ was $96.3 \%$. This suggested that $96.3 \%$ of the response to the hydroxyl free radical scavenging rate was caused by changing the concentration of A, B, and C and by their interactions. Two-dimensional contours revealed that hydroxyl free radical scavenging rate changed with changes in the temperature, whey powder, and calcium lactate concentration, and their corresponding three-dimensional response surface were generated to better determine the interaction of the three variables with the corresponding variables $(\mathrm{AB}, \mathrm{BC}, \mathrm{AC}$, Figure 3$)$. The contour plots seemed to be elliptical or nearly circular. This implied that $A B, A C$, and $B C$ had mutual interactions affecting the hydroxyl free radical scavenging rate, while $\mathrm{AB}$ and $\mathrm{BC}$ were weak interactors in this respect $\left(p_{\mathrm{AB}}=0.3442>0.05, p_{\mathrm{BC}}=0.6430>0.05\right)$. In addition, there was not a simple linear correlation between the variables, calcium lactate, casein peptone, and hydroxyl free radical scavenging rate $\left(p_{\mathrm{A}}^{2}=0.0012<0.01, p_{\mathrm{C}}^{2}=0.0046<0.01\right)$.
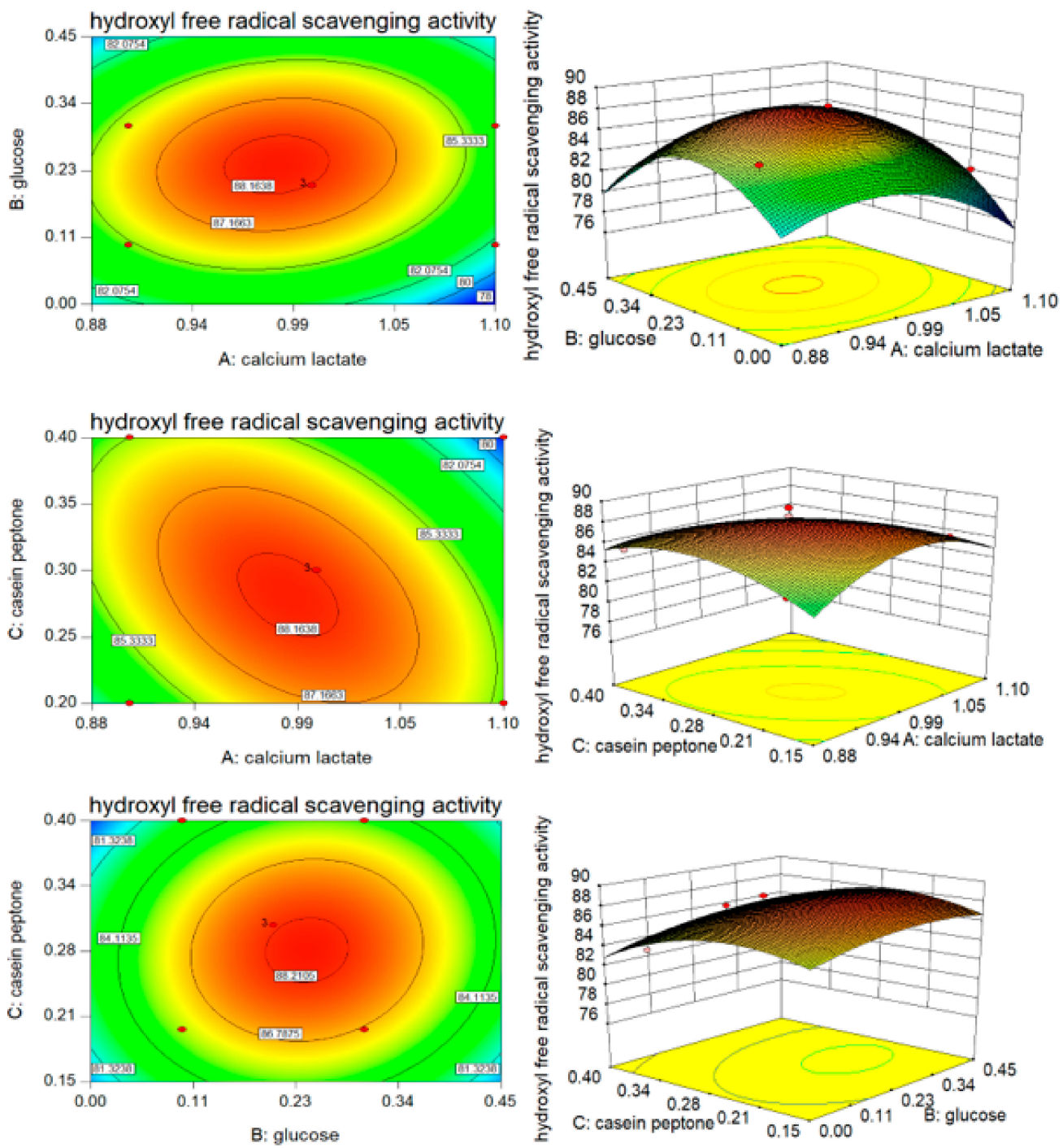

Figure 3. Contour plots and response surface plots of calcium lactate (A), glucose (B), and casein peptone $(\mathrm{C})$ for the hydroxyl free radical scavenging rate $\left(\mathrm{Y}_{1}\right)$. 
The ANOVA showed that the model for the DPPH radical scavenging rate had a $p$-value $<0.01$, which was statistically significant (Table 6). The model equation was corroborated to be a suitable model to describe the value of the DPPH radical scavenging rate, while the lack of fit $(p=0.0854>0.05)$ was insignificant. The value of $\mathrm{R}^{2}$, which was $97.96 \%$, indicated that only $2.02 \%$ of the variability on the $\mathrm{DPPH}$ radical scavenging rate could not be explained by the predicted equation of model. The $p$-value of BC was 0.2759 , which suggested that A and B had a strong mutual interaction affecting the DPPH radical scavenging rate (Figure 4 ).
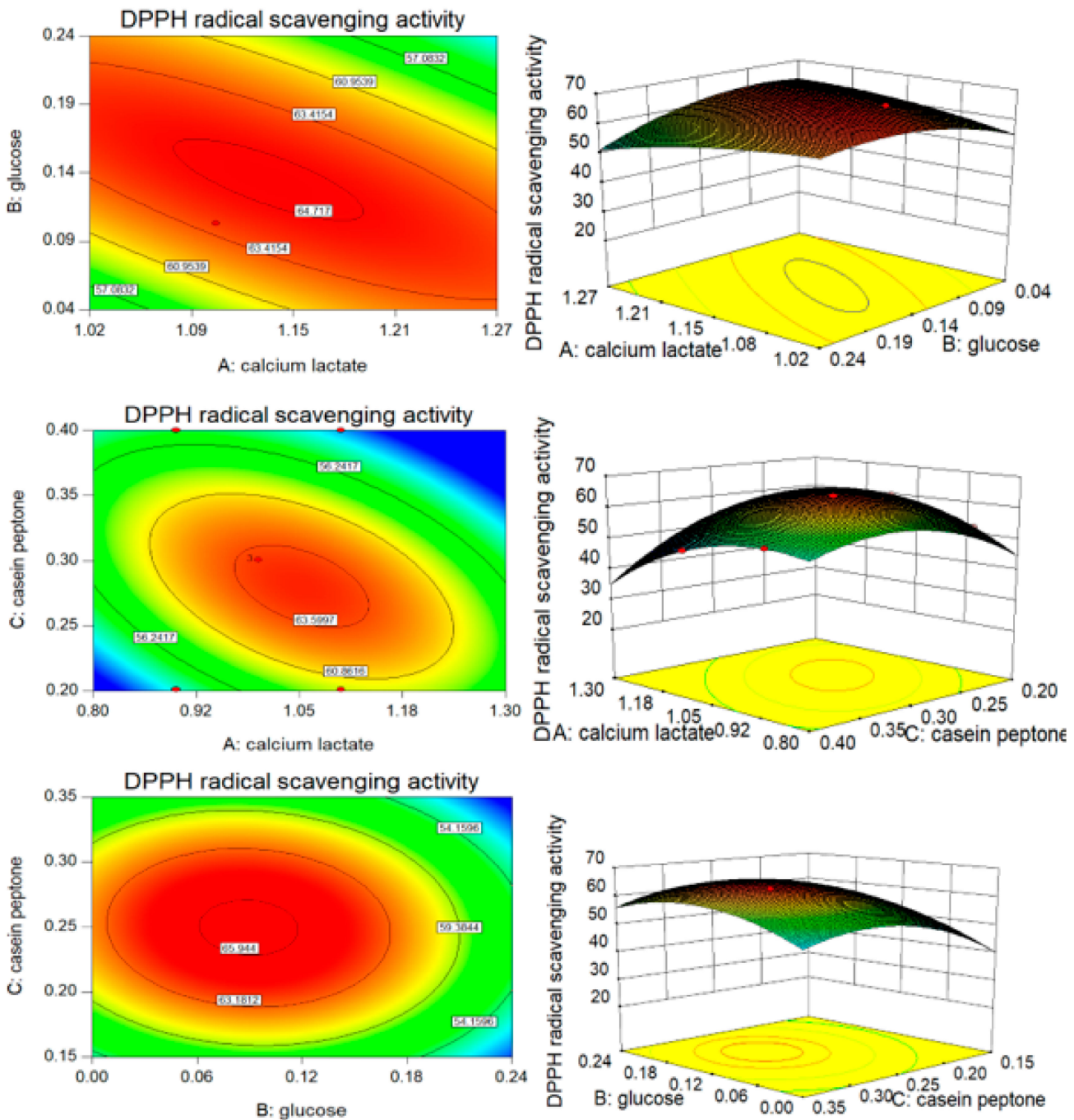

Figure 4. Contour plots and response surface plots of calcium lactate (A), glucose (B), and casein peptone $(\mathrm{C})$ for the DPPH radical scavenging rate $\left(\mathrm{Y}_{2}\right)$.

The maximum responses values of the hydroxyl free radical scavenging rate $(88.36 \%)$ and DPPH radical scavenging rate $(63.79 \%)$ were obtained at additive amounts of $0.99 \%(w / v)$ calcium lactate, $0.21 \%(w / v)$ glucose, and $0.29 \%(w / v)$ casein peptone as predicted. The design of the verification experiment was dependent on the optimization results ( $\mathrm{A}=0.99 \%, \mathrm{~B}=0.21 \%, \mathrm{C}=0.29 \%)$. The results demonstrated that the hydroxyl free radical scavenging rate and DPPH radical scavenging rate were $88.01 \pm 0.69 \%$ and $63.48 \pm 1.22 \%$ under the optimum conditions $(n=3)$. There was no significant difference from the predicted values, indicating the model was appropriate. The control had a scavenging rate of hydroxyl free radical of $56.50 \pm 0.57 \%$ and a scavenging rate of DPPH radical of $41.97 \pm 0.72 \%$ without addition of calcium lactate, glucose, and were peptone $(n=3)$. The hydroxyl free radical scavenging rate and DPPH radical scavenging rate was increased by $31.51 \%$ and $21.51 \%$, respectively, after optimization by RSM. 


\subsection{Simulated Gastrointestinal Digestion}

We isolated and purified the antioxidant peptides and evaluated their stability in simulated gastrointestinal fluids at different periods of time. The results are shown in Figures 5 and 6.

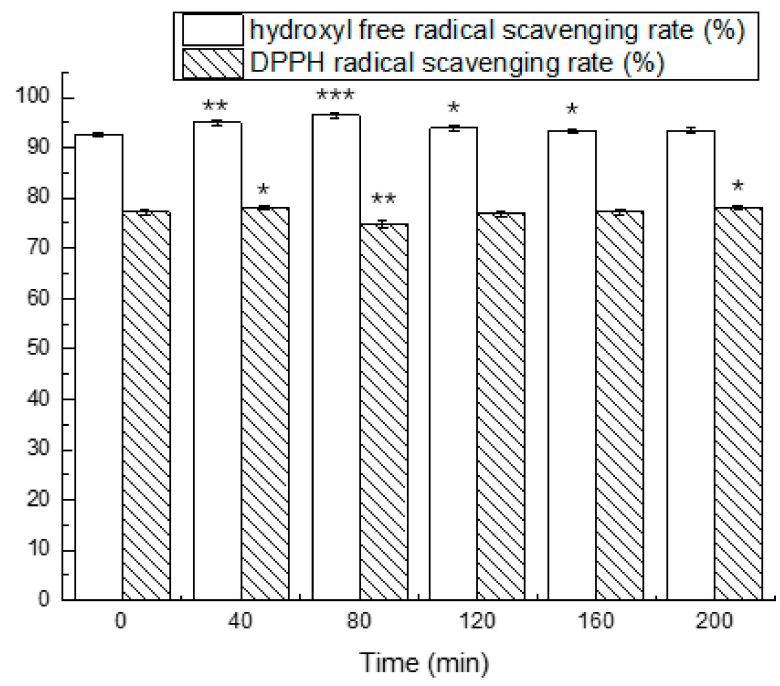

Figure 5. Effects of simulated gastric fluid on the hydroxyl free radical scavenging rate and DPPH radical scavenging rate at different times. The asterisks $\left(^{*}\right)$ indicate significant differences ${ }^{* * *} p<0.001$, extremely significant; ${ }^{* *} p<0.01$, very significant; ${ }^{*} p<0.05$, significant.) of antioxidant activity in the simulated gastric fluid during different times compared to $0 \mathrm{~min}$. Mean values $(n=3) \pm$ standard error are shown.

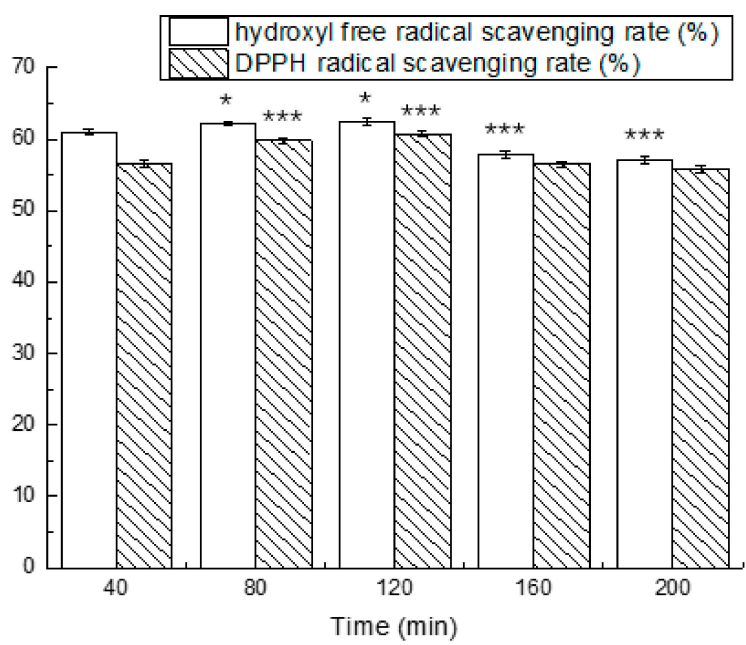

Figure 6. Effects of simulated intestinal fluid on the hydroxyl free radical scavenging rate and DPPH radical scavenging rate at different times. The asterisks $\left(^{*}\right)$ indicate significant differences $\left({ }^{* * *} p<0.001\right.$, extremely significant; ${ }^{*} p<0.05$, significant.) of antioxidant activity in the simulated intestinal fluid during different times compared to $40 \mathrm{~min}$. Mean values $(n=3) \pm$ standard error are shown.

The results from the exposure of antioxidant peptides to simulated conditions of the stomach demonstrated a changed antioxidant activity. The antioxidant activity in simulated gastric fluid for $40 \mathrm{~min}$ were significantly higher compared to $0 \mathrm{~min}$. The scavenging rate of the hydroxyl free radical and DPPH radical at different times ranged from $92.59 \pm 0.45 \%$ to $96.44 \pm 0.55 \%$ and $74.86 \pm 0.66 \%$ to $78.13 \pm 0.38 \%$, respectively. After exposure to simulated intestinal fluid for $40 \mathrm{~min}$, the hydroxyl free radical scavenging rate decreased to $60.99 \pm 0.46 \%$, which was reduced by $34.02 \%$, and the DPPH 
radical scavenging rate was reduced by $13.49 \%$. The antioxidant activity eventually reached the maximum in $120 \mathrm{~min}$.

\section{Discussion}

A great amount of antioxidant peptides is released from goat milk by fermentation. Lactic acid bacteria and yeasts are employed to produce antioxidant peptides during fermentation [19]. The strain L. casei L61, with high antioxidant peptides production capacity, was screened and selected as a starter culture to increase the antioxidant activity of fermented goat milk. It was reported that $L$. casei was a high antioxidative bacterial strain $[20,21]$.

Conditions promoting the production of antioxidant peptides were optimized once the starter and the substrate were determined. A study by Shu et al. [22] showed that the optimal process parameters for producing antioxidative peptides from goat casein hydrolysate were $\mathrm{pH}$ of 8.9 at $62.5^{\circ} \mathrm{C}$ with a hydrolysis time of $173 \mathrm{~min}$. The optimum conditions for the production of antioxidant peptides from goat placenta powder with pepsin were investigated [23]. The antioxidant activity was significantly affected by the hydrolysis temperature, $\mathrm{pH}$, and enzyme-to-substrate ratio.

The culture conditions for lactic acid bacteria growth are strict and generally require a carbon source, a nitrogen source, inorganic salts, and prebiotics [24]. These nutrients are not only conducive to the growth of bacteria, but also promote the production of proteases by lactic acid bacteria. Therefore, it is necessary to optimize the composition of a fermentation mixture. However, there are few studies focused on raising the yield of antioxidant peptides by adding nutrients during fermentation. Our research suggests that casein peptone, glucose, and calcium lactate had significant effects on the antioxidant peptides production from goat milk fermented by L. casei L61.

Calcium lactate has a promoting effect on the antioxidant activity. It was reported that ionic calcium could increase the yield of ACE inhibitory peptides when using L. casei as a starter during fermentation [25]. The promoting effect of calcium lactate on bioactive peptides is strong and can be attributed to the promotion of Lactobacillus growth. Addition of calcium lactate could promote the growth of Lactobacillus bulgaricus [26]. A large amount of proteases was produced and released during L. casei L61 proliferation, which resulted in a high antioxidant activity.

As a monosaccharide, glucose can be absorbed directly by L. casei L61 and then take part in the glycolytic pathway. Thus, there is a positive impact on cell metabolism by an appropriate concentration of glucose, which induces protein hydrolyzation to produce more antioxidant peptides. However, glucose at high concentrations may result in the elevation of the cell osmotic pressure, which is destructive to $L$. casei L61 growth. Moreover, glycated casein with glucose fermented by L. casei 4B15 exhibited significantly higher radical scavenging activities than intact casein. This is probably attributed to the formation of chemical substances with reducing capacity, since heterocyclic compounds and hydroxyl groups were formed during the stages of the glycation reaction $[27,28]$.

Antioxidant peptides are released from proteins fermented by L. casei L61, and their antioxidant activity depends on the type of the original protein [29]. Casein is the main source of active peptides in fermented milk [30]. Studies have shown that the addition of caseinate can significantly increase the release of active peptides during fermentation [31]. A casein peptone supplement increased the amount of fermentation substrates in goat milk, which leads to a higher yield of antioxidant peptides.

Since the antioxidant peptides produced in goat milk fermented by L. casei L61 are expected to remove free radicals in the human body, the stability of the antioxidant peptides in a simulated gastrointestinal tract was evaluated. These experiments revealed a slow increase of the hydroxyl free radical scavenging rate in simulated gastric conditions during $80 \mathrm{~min}$, which could be attributed to the fact that pepsin breaks down the antioxidant peptides in fermented goat milk into smaller peptides with antioxidant activity. The antioxidant activity was decreased after exposure to simulated intestinal fluids, indicating that more small peptides without antioxidant activity were generated. A study by You et al. [32] suggested that more peptide bonds were broken using pancreatin digestion than pepsin digestion. 


\section{Conclusions}

In this study, the effects of the addition of a nutrients formula on the antioxidant activity of goat milk fermented with L. casei L61 were investigated by P-B design and RSM. In addition, experiments of simulated gastrointestinal digestion were performed to evaluate the stability of the antioxidant peptides from fermented goat milk. The results showed that calcium lactate, glucose, and casein peptone had significant effects on the antioxidant activity of fermented goat milk, and the optimal composition of the nutrient formula was found to be calcium lactate $0.99 \%(w / v)$, glucose $0.21 \%(w / v)$, and casein peptone $0.29 \%(w / v)$. The hydroxyl radical scavenging rate increased significantly from $56.50 \pm 0.57 \%$ to $88.01 \pm 0.69 \%$, and the DPPH radical scavenging rate reached $63.48 \pm 1.22 \%$ from $41.97 \pm 0.72 \%$ under the optimal conditions. Both responses were close to the predicted values, which indicated the effectiveness of the model. In addition, the antioxidant activity remained high after incubation in simulated gastrointestinal tract conditions. The optimal nutrient formula supplement could be a good reference for preparing antioxidant peptides from goat milk.

Author Contributions: G.S. and X.S. contributed to the analysis and interpretation of data and wrote the manuscript; L.C., J.K., J.M., and H.C. critically revised the article; L.C., J.K. contributed to the design of the study. J.M. and H.C. conceived the study. All authors read and approved the submitted version.

Funding: The work was funded by the key project of Science and Technology Department of Shaanxi Province (No. 2018ZDXM-NY-085), the Science and Technology Project of Weiyang District, Xi'an City (No.201831), the Scientific Research Program Funded by Shaanxi Provincial Education Department (No. 17JF005), the Science and Technology Project of Xianyang city (No. 2017K02-69).

Conflicts of Interest: The authors declare no conflict of interest.

\section{References}

1. Zielińska, E.; Baraniak, B.; Karaś, M. Antioxidant and anti-inflammatory activities of hydrolysates and peptide fractions obtained by enzymatic hydrolysis of selected heat-treated edible insects. Nutrients 2017, 9, 970. [CrossRef] [PubMed]

2. Nemzer, B.; Chang, T.; Xie, Z.; Pietrzkowski, Z.; Reyes, T.; Ou, B. Decrease of free radical concentrations in humans following consumption of a high antioxidant capacity natural product. Food Sci. Nutr. 2014, 2, 647-654. [CrossRef] [PubMed]

3. Dröge, W. Free radicals in the physiological control of cell function. Physiol. Rev. 2002, 82, 47-95. [CrossRef] [PubMed]

4. Girgih, A.T.; Alashi, A.M.; He, R.; Malomo, S.A.; Raj, P.; Netticadan, T.; Aluko, R.E. A novel hemp seed meal protein hydrolysate reduces oxidative stress factors in spontaneously hypertensive rats. Nutrients 2014, 6 , 5652-5666. [CrossRef] [PubMed]

5. Chamila, N.; Wu, J. Hen egg as an antioxidant food commodity: A review. Nutrients 2015, 7, 8274-8293. [CrossRef]

6. Halliwell, B.; Whiteman, M. Measuring reactive species and oxidative damage in vivo and in cell culture: How should you do it and what do the results mean? Brit. J. Pharmacol. 2004, 142, 231-255. [CrossRef] [PubMed]

7. Ianniello, R.G.; Ricciardi, A.; Parente, E.; Tramutola, A.; Reale, A.; Zotta, T. Aeration and supplementation with heme and menaquinone affect survival to stresses and antioxidant capability of lactobacillus casei strains. LWT-Food Sci. Technol. 2015, 60, 817-824. [CrossRef]

8. Ahmed, A.S.; El-Bassiony, T.; Elmalt, L.M.; Ibrahim, H.R. Identification of potent antioxidant bioactive peptides from goat milk proteins. Food Res. Int. 2015, 74, 80-88. [CrossRef] [PubMed]

9. Belewu, M.A.; Aiyegbusi, O.F. Comparison of the mineral content and apparent biological value of milk from human, cow and goat. J. Food Technol. Afr. 2002, 7, 9-11. [CrossRef]

10. Park, Y.W.; Juárez, M.; Ramos, M.; Haenlein, G.F.W. Physico-chemical characteristics of goat and sheep milk. Small Rumin. Res. 2007, 68, 88-113. [CrossRef]

11. Lópezaliaga, I.; Díazcastro, J.; Ma, J.M.A.; Barrionuevo, M.; Campos, M.S. A review of the nutritional and health aspects of goat milk in cases of intestinal resection. Dairy Sci. Technol. 2010, 90, 611-622. [CrossRef]

12. Haenlein, G.F.W. Goat milk in human nutrition. Small Rumin. Res. 2004, 51, 155-163. [CrossRef] 
13. Sommerer, N.; Salles, C.; Promé, D.; Promé, J.C.; Quéré, J.L.L. Isolation of oligopeptides from the water-soluble extract of goat cheese and their identification by mass spectrometry. J. Agric. Food Chem. 2001, 49, 402-408. [CrossRef] [PubMed]

14. Li, Z.; Jiang, A.; Yue, T.; Wang, J.; Wang, Y.; Su, J. Purification and identification of five novel antioxidant peptides from goat milk casein hydrolysates. J. Dairy Sci. 2013, 96, 4242-4251. [CrossRef] [PubMed]

15. Gupta, A.; Mann, B.; Kumar, R.; Sangwan, R.B. Identification of antioxidant peptides in cheddar cheese made with adjunct culture Lactobacillus casei ssp. casei 300. Milchwiss. Milk Sci. Int. 2010, 65, 396-399.

16. Kong, B.H.; Xiong, Y.L. Antioxidant activity of zein hydrolysates in a liposome system and the possible mode of action. Agric. Food Chem. 2006, 54, 6059-6068. [CrossRef] [PubMed]

17. Kazuko, S.; Kuniko, F.; Keiko, Y.; Takashi, N. Antioxidative properties of xanthan on the autoxidation of soybean oil in cyclodextrin emulsion. J. Agric. Food Chem. 1992, 40, 945-948. [CrossRef]

18. Cruzhuerta, E.; Garcíanebot, M.J.; Miralles, B.; Recio, I.; Amigo, L. Caseinophosphopeptides released after tryptic hydrolysis versus simulated gastrointestinal digestion of a casein-derived by-product. Food Chem. 2015, 168, 648-655. [CrossRef] [PubMed]

19. Parrella, A.; Caterino, E.; Cangiano, M.; Criscuolo, E.; Russo, C.; Lavorgna, M.; Isidori, M. Antioxidant properties of different milk fermented with lactic acid bacteria and yeast. Int. J. Food Sci. Tech. 2012, 47, 2493-2502. [CrossRef]

20. Zhang, S.; Liu, L.; Su, Y.; Li, H.; Sun, Q.; Liang, X.; Lv, J. Antioxidative activity of lactic acid bacteria in yogurt. Afr. J. Microbiol. Res. 2011, 5, 5194-5201. [CrossRef]

21. Jain, S.; Yadav, H.; Sinha, P.R. Antioxidant and cholesterol assimilation activities of selected lactobacilli and lactococci cultures. J. Dairy Res. 2009, 76, 385-391. [CrossRef] [PubMed]

22. Shu, G.; Wang, Z.; Chen, L.; Zhang, Q.; Xin, N. Enzymolysis technology optimization for production of antioxidant peptides from goat milk casein. Acta Univ. Cibiniensis. 2017, 21, 51-60. [CrossRef]

23. Song, X.Y.; Gao, Y.X.; Fang, Y. Optimization of antioxidant peptide production from goat placenta powder using RSM. Food Sci. Technol. 2008, 33, 237-241.

24. Chen, H.; Kou, J.; Hu, M.; Shu, G. Optimization of nitrogen source for Bifidobacterium bifidum using response surface methodology. Acta Univ. Cibiniensis 2016, 20, 53-64. [CrossRef]

25. Gonzalez-Gonzalez, C.R.; Tuohy, K.M.; Jauregi, P. Production of angiotensin-i-converting enzyme (ACE) inhibitory activity in milk fermented with probiotic strains: effects of calcium, $\mathrm{pH}$ and peptides on the ACE-inhibitory activity. Int. Dairy J. 2011, 21, 615-622. [CrossRef]

26. Shi, X.; Chen, H.; Meng, J.; Xin, N.; Ji, Z. Application of Plackett-Burman design in screening ACE inhibitory peptides-producing conditions and media for Lactobacillus bulgaricus LB6. Acta Sci. Pol. Technol. Aliment. 2018, in press. [CrossRef] [PubMed]

27. Gu, F.L.; Jin, M.K.; Abbas, S.; Zhang, X.M.; Xia, S.Q.; Chen, Z.X. Structure and antioxidant activity of high molecular weight maillard reaction products from casein-glucose. Food Chem. 2010, 120, 505-511. [CrossRef]

28. Oh, N.S.; Joung, J.Y.; Lee, J.Y.; Kim, Y.; Kim, S.H. Enhancement of antioxidative and intestinal anti-inflammatory activities of glycated milk casein after fermentation with Lactobacillus casei $4 \mathrm{~B} 15$. J. Agric. Food Chem. 2017, 65, 4744-4754. [CrossRef] [PubMed]

29. Skrzypczak, K.W.; Gustaw, W.Z.; Jabłońska-Ryś, E.D.; Michalak-Majewska, M.; Sławińska, A.; Radzki, W.P.; Gustaw, K.M.; Waśko, A.D. Antioxidative properties of milk protein preparations fermented by polish strains of Lactobacillus helveticus. Acta Sci. Pol. Technol. Aliment. 2017, 16, 199-207. [CrossRef] [PubMed]

30. Miguel, M.; Contreras, M.M.; Recio, I.; Aleixandre, A. ACE-inhibitory and antihypertensive properties of a bovine casein hydrolysate. Food Chem. 2009, 112, 211-214. [CrossRef]

31. Leclerc, P.L.; Gauthier, S.F.; Bachelard, H.; Santure, M.; Roy, D. Antihypertensive activity of casein-enriched milk fermented by Lactobacillus helveticus. Int. Dairy J. 2002, 12, 995-1004. [CrossRef]

32. You, L.; Zhao, M.; Regenstein, J.M.; Ren, J. Changes in the antioxidant activity of loach (Misgurnus anguillicaudatus) protein hydrolysates during a simulated gastrointestinal digestion. Food Chem. 2010, 120, 810-816. [CrossRef]

(C) 2018 by the authors. Licensee MDPI, Basel, Switzerland. This article is an open access article distributed under the terms and conditions of the Creative Commons Attribution (CC BY) license (http://creativecommons.org/licenses/by/4.0/). 